\title{
nature
}

\section{Sustainable outcomes from Gleneagles}

\author{
African nations will be more likely to support development projects whose outcomes are indispensable \\ to them. Participants at next week's G8 summit should focus aid in this direction.
}

\begin{abstract}
$\Lambda^{t}$ a summit meeting in Scotland next week, leaders of the Group of Eight (G8) industrialized nations are set to sign a deal on debt and aid that could see billions of dollars in fresh money flow into African development projects. Some of these projects will have a sizeable research component, as science and technology have been climbing up the development agenda (see the Special Report on page 1146).

The G8 leaders won't meet directly with African leaders, however: South Africas president, Thabo Mbeki, attending as a guest, will be the continent's sole representative. This disconnect unintentionally reflects the historic divide between aid donors and recipients: the former frequently fail to consult adequately with the latter. Huge sums have been wasted because the solutions previously offered to African communities were not integrated into their everyday needs. As a result, the continent is strewn with the debris of unsuitable donated plant and equipment.
\end{abstract}

\section{Local support}

The stated priority of donors for many years now has been to focus on projects that will be sustainable when foreign support runs out. Some progress has been made in the design of such projects in sectors such as education and health. One challenge for the scientific community is to apply the same logic to development-oriented science and technology projects. Planners need to make sure that these projects are indispensable, so that local people and politicians will support them when the aid money has gone.

The approach has already been tested in some instances. In rural Kenya, for example, poor farmers in remote areas can now call on the services of paravets - local people given basic training in veterinary

"Planners need to make

sure projects are

indispensable, so African

politicians will support

them when the aid

money has gone." practice. Foreign non-governmental organizations taught and equipped interested rural people a decade ago, and the paravets now earn a living by charging farmers for their services.

Donor organizations say that this service has been welcomed locally, as professional vets are in such short supply. The inclusion of traditional remedies has made farmers more willing to accept the paravets, project planners say. After the scheme became established, donors were able to take a back seat, leaving the paravets and the national veterinary service to carry the scheme forward. The project is well placed to survive without additional aid.

This kind of approach is easier in some science-related areas than others. It is hard to apply it, for example, in biomedical research. Rich nations currently support malaria research efforts in African labs, and would like to deepen the involvement of African government agencies in them. But the development of drugs or vaccines is a lengthy process, and the other problems facing African governments - such as security, drought, malnutrition, poverty - are immediate. So malaria research is seldom seen as indispensable. Better malaria treatments are important to the future of Africa, but funding for their development is most likely to come from abroad.

Activity in other branches of science, such as meteorology, can be tied more convincingly to immediate needs. The impoverished desert nation of Chad, for example, has scant physical infrastructure and no research budget. But Samuel Mbainayel, a meteorologist in the city of N'Djamena, broadcasts his forecasts to rural farmers by radio every week. African specialists believe that his efforts could be broadened to provide valuable long-term weather forecasts, helping the government to plan - and the farmers to plant.

To get these forecasts up and running, money is needed to improve the capability of African meteorology services (see Nature $435,863 ; 2005)$. Researchers have to be trained and university labs upgraded. These are things that donors are relatively good at. Once the improved forecasts are in place, and they start saving lives, aiding farmers and boosting yields, African governments are more likely to fund the system themselves. In the words of one British aid official, the meteorology services "will pay their own way".

\section{Success on the ground}

This philosophy has already borne fruit in agricultural research. Africa has had some home-grown successes in this field, such as the New Rice for Africa. Developed at the Africa Rice Center in Benin with the help of donor money, this new strain of high-yielding, drought-resistant rice is now being planted in several west African countries. Such successes have helped persuade African leaders to found an agricultural research centre in Kenya under the auspices of a continent-wide, self-supporting strategy called the New Partnership for Africa's Development.

Britain's prime minister, Tony Blair, as host of the summit, has selected Africa and climate change as the two main strands for discussion. On the latter, he can expect little progress. The United States has rebuffed all of his efforts to restart international negotiations over greenhouse-gas emissions targets, and the summit communiqué, if leaks of the draft are correct, may fail even to acknowledge the scientific reality of anthropogenic climate change, as described by the world's scientific academies on 7 June.

The summit's slim chances of success, therefore, ride on its agreeing a convincing package of additional aid and debt write-offs for Africa. Of course, if the participants really wanted to help Africa, they'd be talking about implementing their unfulfilled promises to reduce the massive agricultural subsidies that keep African farmers' produce out of rich country's markets. But debt relief and additional aid, carefully spent on sustainable projects, could still make some long-term difference to Africa's prospects. 